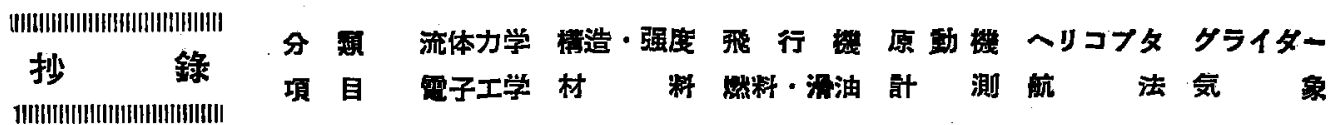

\section{流 体力学}

1. ラパル・ノズルを過ぎる嘅速流に関するホ ドグラフ方程式の二三の解について On some solutions of the hodograph equation which yield transonic flows through a Laval nozzle. F. E.

Ehlers. J. Aero. Sci. 22, 2 (1955/2) 107-123.

算密なホドグラフ方程式に Loewner の変換を用い て，M数 0.8 から 1.35 までの間で，きわめて近似 のよいガスを仮定する事にしてて，基楚方程式を Tricomi の微分方程式の型に与えた. Tricomi が初めて 解いた極座標による一般解を便って，音速で特異点を 持つ特解から，ラバル管の中の流れを計算し，(i) 音 速線が流れに向って凹で，加速度か正なる解 (ii) 壁 の曲率が不連続であるような解 (iii) 軸上だけで音速 線の曲率が零で，加速度もまた零なる解（iv）また特 に，音速線力淔線で，加速度も零といら解 る 得られ た、これらの解に，流域で正則な解を電社合せる事に よって，特別の要求を满たす解も作る事ができる。 そ の一例として，Falkovich が双一次变換を用いて誘道 した arctangent singularity を持つ特解が示されて ある. その他，変数分離法によって得られる解，Tri-

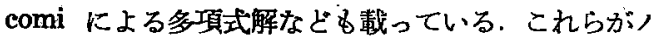
ズルの設言十の際の遷音速領域の解として碀光る事は勿 論である。すなわちまず上に得られた解で，適当に速 度 $(M \geq 1.10$ がよい) 一定の曲線を選び，次いでそ の曲線と軸上の点とから特性曲線法によって流れの場 を作り，希望の速度か軸上に表机るまで計算を進め， 次に Prandtl-Meyer の流れによって，壁の形を決め $て$ ，一様流を得るよらにすればよい（村崎寿渾）

2. 流れに垂道ならびに平行に置かれた有孔物牌 の特性に関する実験的研究”An experimental study of porosity characteristics of perforated materials in normal and parallel flow. G. M. Stokes, D. D. Davis, Jr. \& T. B. Sellers. NACA TN 3085 (1954/4) 24. 有孔物筫を透音速風洞の测定壁や， 超音風洞の昖散筒に使用する事名ら見て，その特性を あらかじめ調へて㯰く事は重要である．有孔壁を流れ に垂直に置いた場合には，有孔恃性は open ratio $=r_{0}$ （孔の部分の面積比）によってきまり，他の条件は二 次的である，次に实用的に見て，流れに並行に置いた 場合のほらが與味深いので,これについて少し詳しく
記して置く、著者らは，亲す孔を過ってVっなる速度 の jet が一般には斜め媵方に向って流水出ると考え, このよらな場合に jet の最少断面積と，孔の部分の 面積々の比を放出俰数 $\sigma$ 之定義すると，一旅流の速 度を $V_{s}$ として，。は $V_{s} / V_{j}$ の函数として決末る事 を示した. かくして有孔恃性を決める量としての。と $V_{s} / V_{J}$ の曲線を open ratio $=r_{0}$ を parameter とし

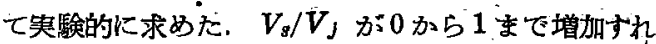
ば，放出係数 。は次第に減少して，注 0.9 加 0 となる．亜音速より超音速流の方が 。はわずかに小 さい，さてたとえば僄音速風洞で有孔壁を使用するよ 弓な場合には, 医力差 $\Delta p$ (suction pressure) と華 淔速度成分 $V_{n}$ の関保を与える所の effective porosity なる概念が有効である. $V_{n}$ を一定に仮定して $\Delta p$ を与え， $V_{J}$ を計算し， $V_{s} / V_{J}$ から。を上述の曲線 によって選び出し，次いで $r_{0}$ を決定するといちょう な具合にして,$\Delta p \sim V_{n}$ 曲線と $\sigma \sim V_{s} / V_{J}$ 曲線を関 聯せしめる事ができる。ここで注目すざき事として， 流出速度 $V_{n}$ を一定と仮定すれば，四出に要する压 力差 $\Delta p$ は主流の速度 $V_{s}$ が增加するととるК急速 に增加する. 実験は $M$ 数 1.3 まで行ったが，音速附 近の様子は央測する事ができないので interpolate 乙 ておる. $M$ 数 1.3 ではまた $\Delta p$ は $V_{n}$ の 1.3 乘に 比例する．最後に，境界層の厚さを $M=1.3 \dot{r_{0}}=0.365$ で求めた所によると， suction を行わない場合にも， 有孔慰の所で境界層は䔳くなる事が示され， $\Delta p=120$ $\mathrm{lb} / \mathrm{ft}^{2}$ の suction を与えれば璄界層はきわめて急速に 減少する事をむ確めた。

（村崎寿满）。

3. 指数法則に従う有孔壁を用いた場合の不积波 の消隇に関する解析 An analysis of shock-wave cancellation and reflection for porous walls which obey an exponential mass-flow pressure-difference rela ion. J. M. Spiegel \& P. J. Tunnell. NACA $T N 322323 . \quad$ 僄音速風洞の有孔壁加便激波の 反射を消滅させるための条件を，蟹を過ぎっての圧力 差 $\left(p-p_{t a n n}\right)$ かi，流れ出寸流量 $\rho V_{n}$ の $m$ 乘に比例 するとい，5境界条件のもとに，二次元の斜め衝激波の， 関保式を使って求めた，との際 $K=\left(\rho V_{n} / \rho_{0} a_{0}\right) / \ell^{\prime}(p$ $\left.\left.-p_{T}\right) / p_{0}\right\}=c\left\{\left(p-p_{T}\right) / p_{0}\right\}^{n}$ なる porosity factor を定義すると便利である．すず suction がない時，

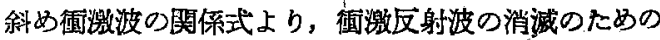
porosity factor $K_{c}$ が，与六られた衙激波の強さ（ $p_{\mathrm{t}}$ $\left.-p_{0}\right) / p_{0}$ に対してきまり，したがって $K_{c} /\left\{\left(p_{1}-p_{0}\right)\right.$ 
$\left./ p_{0}\right\}^{n}=c_{c}$ から $c_{c}$ が求まる. さて央際には $K^{1} /\left\{C p_{1}\right.$ $\left.\left.-p_{0}\right) / p_{0}\right\}^{n}=c$ なる有孔壁を使らとすると反射波を生 ずるが，その強さ $p_{r}=\left(p_{2}-p_{1}\right) / q_{0}$ は，同梯に㣫激波 の関係式を使って $\Delta K / K_{c}=\left(K_{c}-K^{\prime}\right) / K_{c}$ に比例する 事力出て来る. $\Delta K \gtrless 0$ すなわち $c_{e} / c \gtrless 1$ に応して 反射波は王縮または膨脹波である事がわかる，後者の 腿脹波が出る場合には， suction を加える事によって 反射波を消し得る事が，計算によって示される.

一般に, suction によって，有孔性の效きは堿少し て，言い換えれば閉風洞の方向に衝く事がかかる。 た だしこの理論は境界層か存在しないるのと仮定してい るのですって，この事は実際に suction を加える事に よって，相当程度実現され，馬力消費率の点から見て るよいと考元られるのだある範囲の $M$ 数と，瞢激 波の強さとK亘って， suction による反射波の吸収の 可能性が出て来る. 住意の三次元物体に対しても同様 な取披いができる。

（村崎寿渶）

4. 一定温度における二種の気体の乱流喷流混合 について On turbulent jet mixing of two gases at constant temperature. S. I. Pai. Jour. Appl. Mech. 20, 1 (1955/3) 41-47. 著者は 1952 年, 2 種の篗む流体の層流喷流混合についての研究結果を 発表しているが，この論交は一定温度に怙ける 2 種の 気体の 2 次元ならびに軸対称の乱流櫴流混合の場合を 取报い，基碟方程式を導き，この式の一般解法を与え て議論したものである. まず（1）混合気体は連続的 な媒質である (2) 気体の間には化学变化がない(3) 流体唍全気体であり，それ故に各成分気体ならびに 混合気体について完全気体の法則が成立する（4）噴 流混合領域においては境界層の近似が成立する；など の仮定のもとに混合気体の連続の方程式，㹡散の方程 式および連動方程式の 3つの基碟方程式を導く．境界 条件が与えられれば, 未知数 $\rho, u, v$ はこの3つの式の 数值解法などによって求められる.これらの方程式の

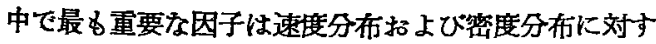
る乱流交換係数 $\left(\varepsilon=-\overline{l v^{\prime}}\right.$ および $\varepsilon_{c}=-\overline{l_{c} v^{\prime}}: l$ およ び $l_{c}$ はそれぞれの分布に対する混合距離）で岕が， 一般にこの二つの最は等しくない、この論文ではまず $E=\varepsilon_{i} / \varepsilon=1$ を仮定し，二つの一様気流の乱流混合を 取报い，速度捛よび密度分布の相低解を求めている. こつの気体の泌度の差が㲺さとして摄動法を用いて いるが(密度か㩐しい均嘪な場合は Görtler の解に

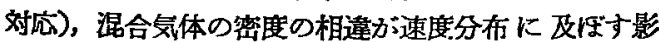
揞は小さい：次に $E=1$ どして，小さい孔からの二 次元ならびに軸対称噴流を取扱い，最後に $\varepsilon_{c}$ と $\varepsilon$ の

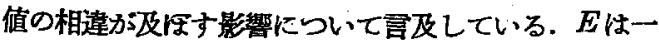
般に 1 より大きく，混合気体における 2 種の気体の崽
度の差か増加するにつれて大きくなる。（过

広)

\section{構 造·强 度}

5. フラッター Flutter. E. G. Broadbent. Flight \& Aircraft Eng. 61, 2242 (1952/1/11) 45-48.

Roy. Aero. Soc. で行われた講演で 2 部に分れてい る. 第 2 部は Kirkby によるフラッター飛行試跧に関 するものである. 本抄録は第 1 部の捛緃翼面フラッタ 一の理論結果を総合したもので，設計中とか原型機の 飛行試䥒中にどんな防止策を講ずべきかを示す.フラ ッターの防止策は，経験上飛行速度上りむ平矢質量の よ5な構造的要素に大きく支配される。(1) 主要な〉 ラッターは主翼曲げ一補助望フラッターと主翼㨝れ一 補助翼フラッターである. 前者は減衰性が大きいが， 補助翼重心か新番線よりすっと啳方にあると励振力を 生じ, 蝶番線上にあると発生しない，後者は減衰力が 小さく的振力す小さいか搞速で発生し易く, 平衡質量 の感度がよくないので制止し難い、胴体曲げ一昇降舵 (方向舵) フラッターも主翼と同しよ5に，節線の位 置によって上記 $\mathbf{2}$ 種類の型式をるつ㑯向がある. (2) 臨 界飛行速度 $V_{c}$ と操緃翼面慣性 $I_{c}$ との関係を論する。 $I_{c}$ の増加は䧗界速度の下限を僅か上昇させても, 上限 すまた増大するので好ましくない，操絽采統剛性の増 加は $I_{c}$ の低下に対応し，高度上年はフラッターの立 場から悪い. (3) 振動節線形状はきわめて重要ですり， 平矣質量の配置法について論するが，最上の方法は前 緑に沿って均一に分布させることで方る. (4) 操綖系 統の自動制御はきわめて複雑な問題を提供する.動力 操緃では平衡質をなくすることは理論上可能である が, 実際例は 1 機のみである. 動力操椗でる質量平衡

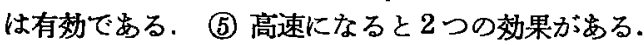

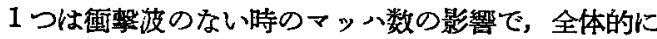
はマット数の増加とともにフラッターか做善される。 2 つ㣫整波自身の存在で，顼性フラッターとか翼 面微振動を括こすことになるが，大したことはない，

(植村益次)

6. 振幅の小さん波板の曲げを受けを場合の安定に วレт The stability in bending of slightly corrugàted plates. D. G. Ashwell. J. Roy. Aero. Soc. (1952/10) 波板力波と直角方向に曲げモーメント を受けたとき，初めは断面二次千ーメントが大きいの で,かなりの抵抗を示すが,曲げモーメントが大になる につれて断面が次第に平面化し，いわゆる flattening を起して，ある值上上になると急激に抵抗が诚じて， 挠略平板に似た現象を呈するが，この現象について詳 紐に解析してある. 前論文 (J.Roy. Aero. Soc. 
1950/8) と同じ筆法で舴析を行っている. 波の方向を スパンとした $\delta l$ なる幅の梁 (transverse beam) に 注目し, anticlastic curvature により中心線が中立 軸でなくなるために生ずる元の梁の軘方向の合力の垂 直分力を荷重として基碟式を誘導している、寺なわち

$$
\frac{d^{4} y}{d x^{4}}+4 x^{4} y=\frac{d^{4} y_{0}}{d x^{4}}
$$

ただし $x$ は transverse beam の長さ方向で $y$ はこ れに垂直な上下方向. $4 \alpha^{4}=12\left(1-\sigma^{2}\right) / d^{\prime} R^{2}$ で $d$ は 板厚， $R$ は元の梁の曲げモーメントを受けたときの曲 承半径, 。はポアソン比, $y_{0}$ は元の波形でする.

一般波形を扱 5 ために $y_{0}$ Fourier seriesに展開 乙，y求めている.すなわら

$$
\begin{aligned}
\frac{y}{d}=\sum_{i}^{\infty} \frac{(2 \pi n)^{4} a_{n} \cos \frac{2 \pi n x}{\lambda}}{(2 \pi n)^{4}+4(\alpha \lambda)^{4}} \\
+\sum_{i}^{\infty} \frac{(2 \pi n)^{4} b_{n} \sin \frac{2 \pi n x}{\lambda}}{(2 \pi n)^{4}+4(\alpha \lambda)^{4}}
\end{aligned}
$$

ただしれは波長，もちろんこれに一般解が加わるはす であるが，上記のものに比してその值は小さいので督 略してある。

これにより曲げモーメントが大になれば $R$ 小にな

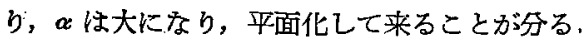

次に曲げモーメントと曲率の関係を求めて

$$
M^{\prime}=1.125 C+6 C \sum_{1}^{\infty} \frac{n^{8}\left(a_{n}{ }^{2}+b_{n}^{2}\right)}{\left(n^{4}+0.00684 C^{2}\right)^{2}}
$$

を得ている、ただし $\sigma=1 / 3$ で計算し， $M^{\prime}=12 M \lambda$ / $E d^{4}, C=\lambda^{2} / R d$ で $a_{n}, b_{n}$ はいすれれ Fourier 係数 だする。

例として正弦波形，三角折線，の場合を举げて， $M^{\prime} \sim C$ 曲線を記しているが，中です，波形が連続的 なものよりも一波長のるのを間隔をむけてその間汁直 線で結ばれているよ5ないわゆる hump 型の波形の ものの方がり強い抵抗を示すことを指摘している点 力興味深い。

(鉿木真一)

7. 航空㧼主翼搆造の疲労損甥の算定 The est $i$ mation of fatigue damage in aircraft wing structures. A. H. Chilner J. Roy. Aero. Soc. 58 (1954/ 6) 396-402. 航空機主翼方; 水平飛行中の定常 何重の上に，突風に上る交番荷重を重畳して受ける時 に，その耐久寿命を算定するため，簡単な集棈疲学損 傷法則を用いた：いわゆる疲労限を明確に示さない面 倒な高強度軽合金材料で作られた主翼接手の疫労損傷 を検討乙た. Taylor の突風凟料と 15 個の權造部材に ついての疲労强度疼料とを用い, 本問題を微小籁囲の 突風負荷によって論ずると，最大損管を引き起す突風 速度考值ちに示すような損賃察曲線か得られる，この
曲線は，飛行离变とは無関俰な，特改劣非状をして いるがこのことが本問題を簡単化することになり， 而久寿命は，200 万サイクルの耐久繰返数を与える交 番荷重 (突風速度) のみによって皃とんど支配される ことになる，ある飛行距離当りの疲労損偟は，飛行高 度と大さな関係がある. $12,000 \mathrm{ft}$ 以下と $30,000 \mathrm{ft}$ 以 上の 2 つの高度範囲について研究する．低高度での低 突風は，高高度での突風よりもかなり大きな椇害を与 える. 本研究結果を Walker か提示した設計基準と Williams が算定した寿命と比較する. 本解析法は,

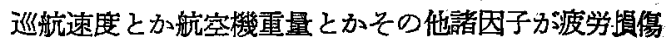
に及ほす効果を研究するのに有用である.（植村益次）

8. 熱応力につ々て Note on thermal stresses. J. L. Bogdanoff. J. Appl. Mech. 21, 1 (1954/3) 88. この論交は二次元熱広力問題を解く際に complex potentials を利用すると便利なことを強調したものて むる. $T(x, y)$ を $x y$ 面の領域 $R$ 内で一様な温度と すると， $R$ 内では $\nabla^{2} T=0$ を㴖足する.ここて $W$ $(x, y)$ を $T(x, y)$ の共斬西数とすると $T+i W=f(z)$, $f(z)$ は $z=x+i y$ の解析函数である. $g(z)=$

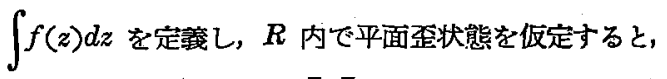
$\sigma_{z}+\sigma_{y}=2\left[\varphi^{\prime}(z)+\overline{\varphi^{\prime}}(\bar{z})\right]$

$$
\begin{aligned}
& \sigma_{x}-\sigma_{y}+2 i i_{x y}=-2\left[\overline{z \varphi^{\prime \prime}}(\bar{z})+\bar{\chi}^{\prime \prime}(z)\right] \\
& X_{\nu}+i Y_{\nu}=-i d\left[\varphi(z)+\overline{z \varphi^{\prime}(\bar{z})}+\bar{\chi}^{\prime}(z) j / d s\right. \\
& 2 \mu(u+i v)=K_{\varphi}(\bar{z})-\overline{z \varphi^{\prime}}(\bar{z})-\bar{\chi}^{\prime}(\bar{z})+2 \mu \beta g(z) \\
& 2 \mu \omega=\left[K \varphi^{\prime}(z)-\bar{\varphi}^{\prime}(\bar{z})+2 \mu \rho f(z)\right]
\end{aligned}
$$

の虚数部を得る.ここでの記昼は. Timoshenko and Goodier “Theory of elasticity", (1951) のむの 同一厄゙り, $\beta \equiv(3 \lambda+2 \mu) \alpha / 2(\lambda+\mu)=(1+\nu) \alpha$, $K \equiv(\lambda+3 \mu) /(\lambda+\mu), \quad \alpha=$ 線膨係数でする.

Biot (Phil. Mag. 19, (1935/3) の理論は上の結果 を㨁接取报ったものであり，Muschelisvili の方法 (Z. a. M. M., 13，(1933)) は $\varphi(z) ; \chi^{\prime}(z)$ を求めるのに 使らことができる。一例として $\boldsymbol{R}$ が半径 $a$ およびb $(a<b)$ の二つの同心凹で囲まれた場合の応力分布学 求めている。 (薑川松男)

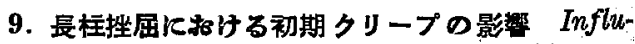
ence of primary creep on column buckling. F. K. Odqvist. J. Appl. Mech., 21, 3 (1954/9) 295.

N.J. Hoff は 1953 年に, フランジの断面がそ化そ れ $A / 2$ なる宁西端回䎐端の長桂のクリープ挫屆につい. て論じたが-N. J. Hoff; Buckling and stability. J. Roy. Aero. Soc., (1953/1)—このとさの挫剭基 礎方程式は Norton の定常クリープにおける power

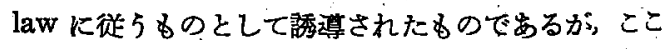
では，著者か㵊近発表した一F.K. G. Odqvist; In- 
fluence of primary creep on stresses in structural parts, 8 th. Intn. Congr. Appl. Mech., Proc. (1953) 99 打よび Influence of primary creep on stresses in structural parts, Trans. Roy. Inst. Tech., Stockholm, Sweden, Nr, 66 (1953) 一に扔 いて取报った方法で初期クリープの影響について考察 を行つたすのでする. この場合のら張クッープに拈け る底力 $\sigma$, 歪 $\varepsilon$, 時間 $t$ の関係は

$$
d \varepsilon / d t=k k_{0} \sigma^{223-1} d \sigma / d t+k o^{n}
$$

ここに $k_{0}, n_{0}, k_{0}$ および $n$ は温度のみによる材料常数 であり，第 1 項か初期クリープの影響を示しており， $k_{0}=0$ のとき，Hoff の使った基楚式となる．たとえば $200^{\circ} \mathrm{C}$ の Al 合金では大約 $n_{0}=2, n=3$ である. また右辺第 1 項は結晶粒内の迄り変形による項で非可 逆であり，第2 項は粘性クリープの項である。したが って柱の非弾性挫屈を取り投う場合には，断面の王簿 側ではこの仮定のままの関保が保をれるが，引張り側 て经底力の恢復が岁るから，この場合には右辺第 1 項 は不要となるすのとして次の形の挫屈方程式を得る。

$$
\begin{aligned}
\frac{\partial^{2} w}{\partial \xi^{2} \partial t}=-\Lambda(1 & +w)^{n_{0}-1} \frac{\partial w}{\partial t} \\
& +\Pi\left[(1-w)^{n}-(1+w)^{n}\right]
\end{aligned}
$$

たでし $\Pi \equiv 2 k(L / \pi h)^{2}(P / A)^{n}, \Lambda \equiv 2 k_{0}(L / \pi h)^{2}$ $(P / A)^{n,}, L=$ 柱の長さ, $h=$ フランジの間隔, $y=$ 撓み， $w \equiv 2 y / h ， \xi \equiv \pi x / L$ である. $\Lambda=0$ のとき Hoff の導入した形となる。

(棠川松男)

10. 檽造部の底力に及侨す初期クリープの影響 Influence of primary ereep on stresses in structural parts. F. K. G. Odqvist. Trans. Roy. Inst. Tech. Stockholm, Sweden 66 (1953). 苂ス・タービ ン,ジェット・エンジンなどのように高温で作動する 機軷认使 弓高度の耐クリープ合金では，そのクリープ 制限底力は同一温度での普通の降伏点応力と比較して

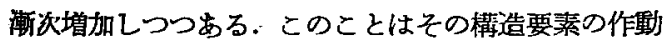
期間中の全クリープ量よりはむしろ初期クリープの量 が重要となってきつつあることを示している. ここで はます弓张りに挌ける単軸応力状態における歪 $\varepsilon_{i j}$, 底 力 $s_{i j}$ 扣よひ時間 $t$ との関係

$$
d \varepsilon_{i j} / d t=f\left(\sigma_{e}\right) s_{i j}+g\left(\sigma_{e}\right) d s_{i j} / d t
$$

(ただし $\sigma_{e} \equiv\left(3 s_{i j} j^{2} / 2\right)^{1 / 2}=$ 有效応力, $f\left(\sigma_{e}\right), g\left(\sigma_{e}\right)$ 快実験で決变函数)と招き, v. Mises の固体の塑性 流理論に徉って一般の 3 次元広力状態に抾張しちるこ

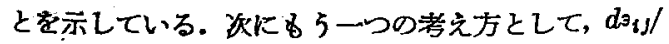
$d t=f\left(\sigma_{e}\right) s_{i}$, for $s_{i j}{ }^{2}<s^{2},=\varphi s_{i j}$, for $s_{i j}{ }^{2}=s^{2}$ t 基禁にした理論を述へている。これは昰速度がその棈 造要素火作用している㢁力状熊によって定まることを 示している. 数値例として中心に円孔のある一様な厚
さの回転円板の計算を行っている.（管川松男）

$$
\text { 原動 機 }
$$

11. 核沸篮における流動抵抗と熱云罢の閣係 $\mathrm{On}$ the relationship between fluid friction and heat transfer in nucleate boiling. J. Amer. Rocket Soc. 25, 1 (1955/1) 9-12. 核饬腾に括ける気泡 の運動か溔伝達と流動抵抗に扣よぼす影響をしらべた 実験的研究である。長さ 43 in, 内径 $3 / 8$ in の不銹 鋼管に電流をながして加熱しその中に水をながす，流 速は約 $18.5 \mathrm{ft} / \mathrm{sec} て ゙ ， R_{e}$ は温度によって 1.4 3.8 $\times 10^{4}$ の簵囲にわたっている. また式力は $265 ， 115$, 65 psi のばあいについて実験している. 核沸騰の状態 に括いては気泡により管の烄効断面積か隇少するの で，流量をでンチュリで則定するととるに管の中にビ トー管を入れてその影響をしらへている.測定結果が

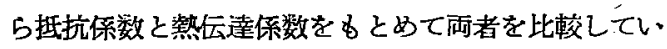
るが，抵抗保数としては

$$
C_{F}=-\left(\frac{p}{d x}\right) \frac{d^{\prime}}{\rho \bar{V}^{2}}
$$

をるちいている.ここで $x$ は管の軸の方向への脣さ で, $d p / d x$ はする位置に括ける $x$ 方向への圧力勾配,

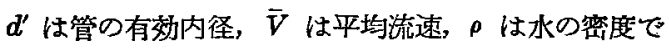

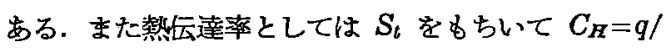
$\rho C \bar{V}\left(t_{w i}-t\right)$ とする. ここで $q$ は単位熱面積岉たり の熱流量で， $t_{w \iota}$ は管の内面の温度， $t$ は水の温度， $C$ はその比熱である. 実験結果 $C_{F}$ と $C_{H}$ のあいだ には $C_{F} / 2=C_{H}$ の関係がなりたつが，これは Rey_ nolds analogy からみちびかれるるのとおなじでする と著者は言及している。

(木村逸郎)

12. ターボ・ジェットの再熱（最近 5 年間の進步） Reheat for turbojet (five years progress reviewed in an R. Ae. S. Lecture). Flight 29 (1954/10) 641643. de Havilland の燃狫研究者 J. L. Edward が 1949 年以降 5 年間のターボ・ジェット再熱に関す る進歩について王立空力学会で 1954 年 10 月汇諢演 したものの概要でする. Vampire と Venom とを使 って櫴口面積，蜘料制御などにつき高空性能，安定性 に及ぼす影響をしらべた，地上でマッハ1.5, 高空で マッハ3.0になるとアフタ・バーナはラム・ジェットと なりターボ・ジェットは二次的のものとなりタービン 出口压はラム压にほぼひとしくなる。がる高空高速 飛行では蜘料噴射法,フレーム・スタビライザーの構 造，各部の高温対策などに種々の考虙を必要とする。 一番辛い状態は高々度で着火する場合で，テイル・パ イブ代力は低く，空気流量は少く，温度が低いからで 
ある. 地上静止時と $60,000 \mathrm{ft}$ ，マッハ0.9 ఏときと では同じ再薙温度に対し燃料量で $6: 1$ 燃圧で $36: 1$ となり地上音速飛行では更にこの比が $92: 1$ となるか ら，かかる広籁囲の燃料噴射が可能なることを要才 る. 嘈射法の主なるすの仙 1) 半径方问のバーから切 線方向燌射するすの，2）輪状のるのから内，外方 向一噴射するものであるが，これを組合せたものがよ い上らで焉る.タービンの上流に然料を噴射する方法 は, “streak ignition”之呼ばれガス温度は燃料維持 に十分でからタービン翼通過中は燃㝋ず飛行状態か変 っても安定性を損わ好という考元方に立っているのだ が实際にはェンジンの温度が上るので好をしくない， 蝳焼については “screech”之称する異常な劇しさの 高周波数の振動が扢こり板金構造やボールトが破損す ることがある.これは共鳴現象でなく強制横振動らし い. スタビライザー直後の瀜による局部的空燃比の変 化か等の供給状況を变えこれが压力波になるかるたは 再䓡の炤からの輻射が早期点火を誘起し熘が正規の位 置と若干上流の不安定な位固との間を前後すると考元 られる。

(领岛 孝)

13. 航空原動挠は進步している Research extends propulsion frontiers. Aviation Week (1955/3/14) 190-214. 航空原動機の発诖方向の解説的展望記 事である.ターボ・ジェットが当分の間主流で，ター ボ・プロップは減速綮車, プロペラ，制御に問題多く 将来は楽観を許さない.ターボ・フォンは試作に金が かかるの灘点でする。再燃装置は小型ジェット・エ ンジンを除き大いに採用される、小型高性能ジェット ・エンジンが将来大いに実用されるよ5になることを 強調して 250 1,000/g の推力筑囲で, 推力/重量が10 というのか可能となり， ○コプタージェット練習 機，輸送機，地上協力機，ミサイルなど広く央用される 仿ろらといっている.ラム・ジェットは飛行機を適当 な速度にする起動垶置を必要とし, 制御, 燃焼に問題 多いが大推力のターボ・ジェットについでラム・ジェ ット時代が来る. ロヶット：将来有望であるが大会社 の仕事にはなりにくい，原子動力：有望，严音速機用 を完成することがまず第一となる5．研究者,設計者, 製造家の三者一体の活躍によってのみ発趿㙨は発達す る.

(今井兼一郎)

\section{燃 料 ·滑 油}

14. テュュホン新石油添加棛フェロシン Seeking profits in the pall. Chem. Week 76, 4. (1955/1/22) 54〜58. デュ・ボンにてカーボオキシヘンタダィ エチル（サイクロヘンタジエニール）鉄を含む新石油
添加削の恃許を得て本奛の通称はフェロシンといい灯 油中に僅かに $0.05 \%$ (重量比) 添加すると発堙傾向 約 $40 \%$ 隇少し,ガンリンに添加するとノック傾向を 著るしく低下ししかも四エチール鉊に何等副作用むな く安定であるなどすこら゙る有望添吅郕でする事を発見

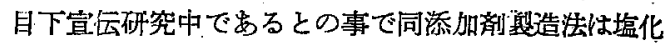
鉄とサイクロペンタジエンのンーダ壏を反応せしめる との事でる。

（小膰武三）

15 新シリコン潤滑油ジェット実用試験に合格す New Silicone lube passes jet tests. Aviation Week

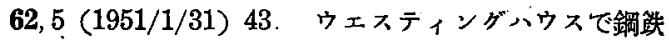
面に対する閏滑性を与えるために特別の化学構造を有 する新シリコン油を合成発明実験空的には MIL-7803 規格による負荷而すかダイエステルとほほ等しく㷫安 定性はより㯪れており，粘度一温度特性はMIL-0-6081 級 1010 油より良く $-65^{\circ} \mathrm{F}$ から $500^{\circ} \mathrm{F}$ 究流動性 と安定性を有すると伝えられている，本品について昨 春ウェスティングハウス・ジェット・エンジンをー ボ・プロップに附けて 15 時間実用試験の結果好結果 を得ていたが今回本油の製造先であるがウ・コーニン グ社より多量に電部に提供試鈳を行った.(小膰武三)

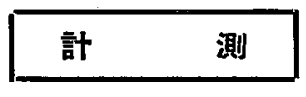

16. ジェット輪送機の計器装偖 Jet instrumentation for jet transports. C. Dykes, Aero. Eng. Rev. 14, $1(1955 / 1)$ 24-32. “普通の誥器, たと 完ば高度計，真速度計，マッ八計，指示速度計，迎角 訳，上昇率計，気温計，自動操緃装置のほ加に，飛行 記録器 (压力塙度, 対気速度, 気温, 燃料流量, 発動 機回転数，ガス温度，時閒）か㴗望される。これは操 緃者の任意が重くなり，上昇括よび降下速度が大きく なったので誌取り時間が短くなり，一方最良の運航条 件を求めるためには統計解析が必要なためてある。 ジェット機になったため必要となる訐器は,ガス温度 計とスラスト計である、ガス温度は，英国に物いてジ エット・パイプ温度，米国ではタービン入口温度を取 るが, 結局に括いて同しことである. 現用のガス温度 計は $\pm 10^{\circ} \mathrm{C}$ の許容誤差で設計されているが，事実は $30^{\circ} \mathrm{C}$ の俁差む珍らしくはない. 計器指度が低過ぎれ ばタービン羽根が過熱して危険ですり，高過ぎれば 不要に絞ることになってパワか減り, 経済的に不利を 招く，ガス温度計の精度が必要なわけでする，また室 気流量が減ればガス温度は急激に上るから，宾気取入 口の結水を知るためにはガス温度訪撮良の指示にな り，したがってその遅れる小さいことを要する.スラ スト訐は発動機の性能を知るためには必須である. (128 面につア゙く) 
$\left[\sigma_{x}\right]_{E}=$ フランジ端部での本理論による值

$\left[\sigma_{x}\right]_{M}=$ フランジ中央部での本理論による值

でする.な扣円形薄肉断面梁の場合には剪断おくれの 影響は全くあらわれず単純理論による結果と一致する ことが判る。これは㧖れの場合と同じような結果で與
味のあることである.

女献

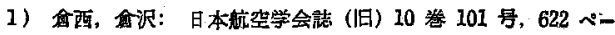
济 (昭 38-9)

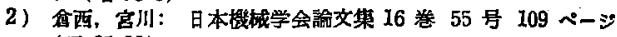
(昭 25-11)

3) E. Reissner: J. Aeron. Sci., Vol. 8, No. 7, p. 284.
(140頁加つずく)

分解の度ごとにスラストが泌ることはよく経跧するこ とである.前後取付㭠の負荷を測る機栰的方式出るい は室気取付口とジェット・パイ゚の圧力を測る方式が 考えられる．機体の寿命を知るためには垂直加速度計 が要求される.たとえば米国で 15,000 時聞の寿命を 持つ機体です，上空で乱れの多いローデシアあるいは 中部塆洲では $6,000 \sim 8,000$ 時間に減ることがある. 機体の着水指示計は空気取大口の場合のよ5な速い応 答は不要だが，着氷の有無と程度がわからぬと，不当 に多量の熱を无縮機またはタービン通風からさくこと になって不経済であ゙る。

ピストン発動機用の計器でも精度を上げないと使い るのにならぬ.たとえば回転計の例を取ると，ビスト 二発動機回転速度の $1 \%$ の变化は㙨速の $3 / 4 \%$ の変 化となるが，ターボ・プロップでは $1.5 \%$ ，ターボ・ ジェットでは実に $4 \%$ \%変化になる. 李た回転計の駆 : 動は従来のよ5に補機軸を通さず，タービン軸から直 接取るべきで, 安定な電子発振器の周波数との差を示 すよらにしたらよい，またピストン発動機に装備され ている同調器も，特にターボ・プロップに必要であ る. 気温はジェット輸送機にきわめて敏感に影響し, コメットI型では，気温が $1^{\circ} \mathrm{C}$ 変れば，巡航宮度は

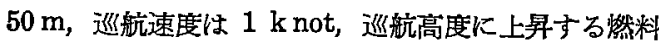
は $30 \mathrm{~kg}$ 変る. 大西洋横断の場合には $2^{\circ} \mathrm{C}$ の気温変

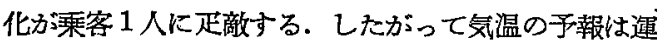
航侸需要である. 現用の気温計は気温よラム温度とを 与えるが，気温だけを測ることができれば機速もかか ることになる.ジェット輸送機では燃料重量が有料荷 重の数倍になるので，正確な燃料訐は経済扣よび安全 の点から重大である. 現用の $2.5 \%$ の許容誤差は過 大どする.

（侁貫亦男）

17. 筑線風速計による相関測定の場合の補正 Corrections in hot-wire correlation measurements.

C. E. Pearson. Quart. Appl. Math. 12, 3 (1954/10) 235-240. 繁線風速計を用いて乱れを測定する場 合, 特に小さいスケールの乱れの相関を湘るときには, 熱線か洧限の長さをるっているから，これに対して補 正を加えねばならぬ.この論文は熱線の end effect,

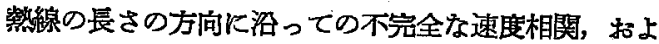
び䔩湶の長さの方向の過渡的な熱伝導を考慮して補正
式を求めたすのである，気流力潪線に垂直にあたる場 合を考光，熱線の一部分についてのエネルギー保存則 から熱線の温度分布（士なわち抵抗分布）をきるる微 分方程式を導く. 速度挌上び抵抗値を定常値と変動值 にわけ，境界条件を考虑してまず定常解を求め，薙線

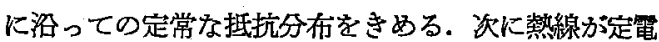
流のもとで作動する場合を考元，定常な抵抗分布を用 いて変動抵抗に対する偏微分方程式を脜き，この式に Fourier 変換を汪どこして常微分方程式に変えて解を るとめる. 熱線の出力䉓压はこの㚆動抵抗を熱線全部 にわたって積分することにより求まる. 次に気流に垂 直な面内に平行に招かれた二本の䓡線で相関を湘る場 合を考光，上にるとめた結果を用いて，測定された (空間的ならびに時間的) 相関函数と真の相関函数と の間の関係をあらわす積分方程式を導く．その結果に よると，2本の缹線の一定の間隔に対して 2 本の熱線 の一定の間隔に対して2本の線を平行にいろいろずら した場合の測定値が判ったときに，この皘分方程式が explicit に解け, 真の相関の值か浗まる. 最後に温度 一定で作動する䓡線の場合について簡単によれてい .3.

(过 広)

18. 飛行榃の重心位置の自動制御 $C-G$ control copes with shifting fuel. R. L. Bergeson. Control Eng. (1955/4) 80-83. 飛行機の重量の大半が燃 料で山るとき，その分布か棌行機全体の重心炏大な 影響をもつ，全体の重心の位置は飛行の安定のため一 定の範囲の中になければならない。乙たがって政料の 分右を制御して，常に全体の重心を大きく動かさない よらにするための自動制御装置が考えられた。それは 燃料の全体重心まわりのモーメントを検出する装置 と，それでェンジンへの燃料を制御するポンプよりな ろ. 一のタンク内の燃料のモーメントは, 然料タンク 内にあるコンデンサーの䉓気容量が燃料の量によって 変わることで検出され，全体のモーメントの偏差は交 流ブリッデの出力となり，それが増幅されりレーを作 動さし，それによって燃料タンクのポンプが切りが られ，全体の重心が一定範囲内にあるよ5に然料が自， 趿的に使用されて叫く、制御の方法は on-off でる が, リレーと回路の組合せで. “snap action” が附加 され振動に対し安定化されている.（穂坂 衙） 